\title{
Analytical Modelling of High Concentrator Photovoltaic Modules Based on Atmospheric Parameters
}

\author{
Eduardo F. Fernández, ${ }^{1,2,3}$ F. Almonacid, ${ }^{3}$ T. K. Mallick, ${ }^{1}$ and P. Pérez-Higueras ${ }^{3}$ \\ ${ }^{1}$ Environment and Sustainability Institute, University of Exeter, Penryn, Cornwall TR10 9EZ, UK \\ ${ }^{2}$ Centro de Investigación en Tecnoloxías da Información (CITIUS), University of Santiago de Compostela, \\ Santiago de Compostela E15782, Spain \\ ${ }^{3}$ Centro de Estudios Avanzados en Energia y Medio Ambiente (CEAEMA), University of Jaen, \\ Campus las Lagunillas, Jaen 23071, Spain
}

Correspondence should be addressed to Eduardo F. Fernández; e.fernandez-fernandez2@exeter.ac.uk

Received 29 October 2014; Accepted 21 December 2014

Academic Editor: Paolo Fornasiero

Copyright (C) 2015 Eduardo F. Fernández et al. This is an open access article distributed under the Creative Commons Attribution License, which permits unrestricted use, distribution, and reproduction in any medium, provided the original work is properly cited.

The goal of this paper is to introduce a model to predict the maximum power of a high concentrator photovoltaic module. The model is based on simple mathematical expressions and atmospheric parameters. The maximum power of a HCPV module is estimated as a function of direct normal irradiance, cell temperature, and two spectral corrections based on air mass and aerosol optical depth. In order to check the quality of the model, a HCPV module was measured during one year at a wide range of operating conditions. The new proposed model shows an adequate match between actual and estimated data with a root mean square error (RMSE) of $2.67 \%$, a mean absolute error (MAE) of $4.23 \mathrm{~W}$, a mean bias error (MBE) of around $0 \%$, and a determination coefficient $\left(R^{2}\right)$ of 0.99 .

\section{Introduction}

High concentrator photovoltaic (HCPV) technology is based on the use of optical devices that focus the sunrays on a high efficiency solar cell with the aim of reducing the cell surface area and therefore to decrease the costs of electricity $[1,2]$. A typical HCPV module is made up of multijunction (MJ) solar cells, interconnected in series or parallel, with one optical device per cell, and with a concentration factor higher than 500x. The optical devices usually consist of a primary optical reflexive or refractive element that collects and concentrates the light and a secondary optical element to homogenize the light on the solar cell surface and improve the overall acceptance angle of the module [3-7]. The efficiencies already reached by MJ solar cells and HCPV modules are noticeable and are continuously being increased [8-12], because this HCPV represents a potential alternative technology to conventional flat photovoltaic systems in the energy generation market with an installed capacity that could reach more than $1 \mathrm{GWp}$ in 2020 [13].
The energy prediction and the modelling of the power output of HCPV devices are important issues to evaluate the potential and promote the market expansion of this emerging technology. However, the modelling and electrical characterization of these devices is complex due to the use of multijunction solar cells and optical elements. In order to address this issue, the scientific community has devoted considerable efforts in developing models that reproduce the electrical performance of HCPV modules [16-19]. These models present different levels of complexity and accuracy and usually need measurements of specific instruments, detailed information of the materials of the modules which is not always available, and advanced knowledge of semiconductor physics, optics, or different specific software.

A different approach for the modelling of HCPV modules based on atmospheric parameters and on a simple mathematical expression has been introduced by Fernández et al. [14]. This model predicts the maximum power of a HCPV module as a function of direct normal irradiance and temperature and introduces a spectral correction based on air mass. The air 
mass is widely accepted as the main parameter that affects the spectral distribution and the electrical output of HCPV modules. However, there are other parameters that play an important role in the spectral distribution of the incident irradiance and power output of HCPV modules. Among these, aerosol optical depth has been demonstrated to be a key parameter since it has a nonnegligible effect in the spectral characterization of these devices [20-25]. Bearing this in mind, the aim of this paper is to introduce an additional spectral correction based on aerosol optical depth in the mathematical model presented by Fernández et al. [14]. The approach is to find a model based on atmospheric parameters and simple mathematical relationships with an optimum balance between accuracy and simplicity in order to facilitate its application.

The paper is organized as follows. In Section 2, the mathematical model is introduced and justified. In Section 3, the experimental campaign to check the quality of the proposed model is described. In Section 4, the analysis of the results in the estimation of the output of a HCPV module is conducted. Finally, the main conclusions are outlined in Section 5.

\section{Mathematical Modelling}

HCPV modules only react to the direct component of the incident irradiance due to the use of optical devices. Taking this into account, the maximum power of a HCPV module can be estimated with the well-known relations used in conventional photovoltaic technology introduced by Osterwald [26] and Evans [27] as a function of direct normal irradiance (DNI) and cell temperature $\left(T_{c}\right)$ as

$$
P=\frac{P^{*}}{\mathrm{DNI}^{*}} \mathrm{DNI}\left(1-\delta\left(T_{c}-T_{c}^{*}\right)\right),
$$

where $P^{*}, \mathrm{DNI}^{*}$, and $T_{c}^{*}$ are maximum power, direct normal irradiance, and cell temperature at standard test conditions; and $\delta$ is the cell temperature coefficient of maximum power.

HCPV modules are based on MJ solar cells and optical devices. In MJ solar cells, each junction responds to a particular band of the spectrum. At the same time, the optical devices modify the spectral distribution that strikes the solar cell surface. Because of this, HCPV modules are strongly affected by the incident spectrum, so that is necessary to introduce a spectral correction in (1). As commented, the air mass (AM) has been identified as the parameter with the largest impact on the spectral distribution and power output of HCPV modules. Because of this, (1) has been rewritten with a spectral correction based on AM by Fernández et al. $[14,28]$ as

$$
\begin{aligned}
P_{\text {module }}= & \frac{P^{*}}{\mathrm{DNI}^{*}} \mathrm{DNI}\left(1-\delta\left(T_{c}-T_{c}^{*}\right)\right) \\
& \times\left(1-\varepsilon\left(\mathrm{AM}-\mathrm{AM}_{\mathrm{U}}\right)\right),
\end{aligned}
$$

where $\varepsilon$ is the air mass coefficient of the maximum power of a HCPV module and $\mathrm{AM}_{U}$ is defined as the umbral air mass. The analysis of performance of HCPV modules in outdoors has indicated that the power output of a HCPV

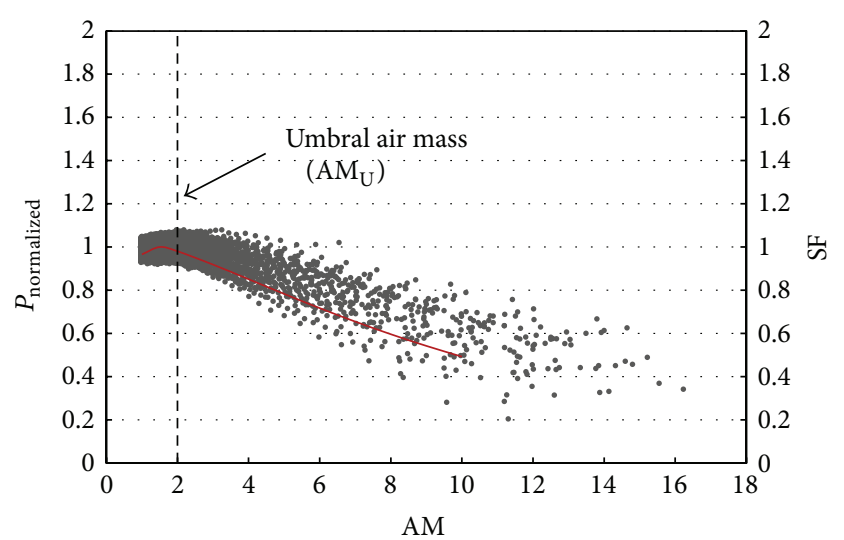

FIgURE 1: Normalized maximum power (grey dots) and spectral factor (red line) versus AM of a HCPV module made up of lattice-matched GaInP/GaInAs/Ge solar cells and poly(methylmethacrylate) (PMMA) Fresnel lenses [14, 15].

module can be considered independent of the air mass for $\mathrm{AM} \leq \mathrm{AM}_{\mathrm{U}}$ and can be corrected with a linear coefficient for $A M>A M_{U}$. This behaviour is shown in Figure 1 where the normalized power of a HCPV module is plotted versus AM (grey dots). For low AM values the top and middle junctions of MJ solar cells of a HCPV module almost generate the same current and therefore the power output can be considered independent of AM. However, as the AM increases the top junction strongly limits the current of the HCPV module reducing its performance. This behaviour is also shown in Figure 1 where the spectral factor (SF) of a HCPV module is plotted versus AM (red line). This factor quantifies the differential performance of a HCPV device between the incident and reference spectra as a function of the mismatch among the different junctions of the respective MJ solar cell: $\mathrm{SF}>1$ indicates spectral gains while $\mathrm{SF}<1$ indicates spectral losses $[15,29,30]$. It is important to note that the $\mathrm{SF}$ reaches a maximum at a certain air mass value, where the top and middle junctions generate the same current, and decreases aside this point due to limiting current by one of the junctions. On the other hand, the power output keeps almost constant and starts decreasing when the SF reaches a certain value. This can be explained since the SF quantifies the performance of a HCPV module through the mismatch among the current of the junctions of MJ solar cells and taking into account that the maximum power shows a lower spectral dependence than the current [31-33].

Equation (2) quantifies the spectral effects by the use of the AM. However, the performance of HCPV modules is also affected by aerosol optical depth (AOD). Therefore, it is adequate to introduce an additional spectral correction based on AOD in order to improve the quality of the model. In order to introduce the appropriate AOD correction, the SF of a HCPV module has been plotted versus aerosol optical depth at $550 \mathrm{~nm}\left(\mathrm{AOD}_{550}\right)$, as shown in Figure 2. As can be seen, the same behaviour to that in the previous case is observed. For low $\mathrm{AOD}_{550}$ values, the top and middle junctions of MJ solar cells of a HCPV module almost generate the same current and as the $\mathrm{AOD}_{550}$ increases the top junction limits the current 


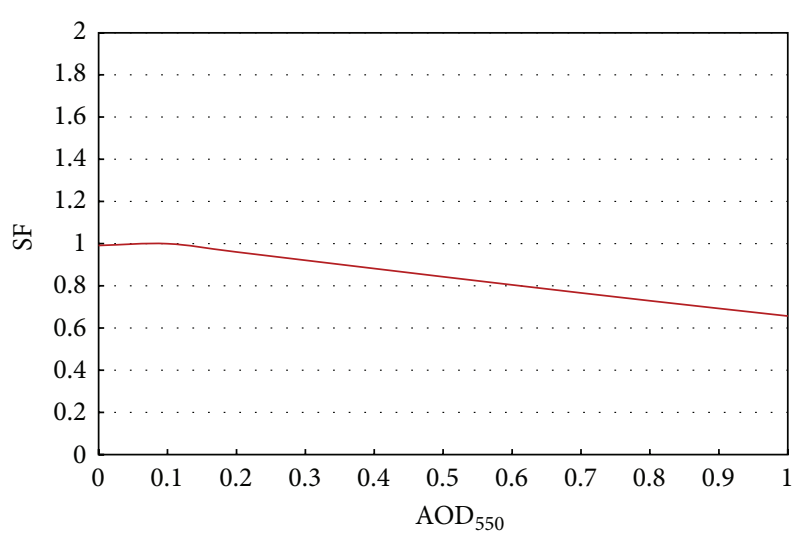

Figure 2: Spectral factor versus $\mathrm{AOD}_{550}$ of a HCPV module made up of lattice-matched GaInP/GaInAs/Ge solar cells and poly(methylmethacrylate) (PMMA) Fresnel lenses [15].

of the HCPV module reducing its performance with a linear behaviour as a function of $\mathrm{AOD}_{550}$. Taking this into account, (2) can be rewritten as

$$
\begin{aligned}
P_{\text {module }}= & \frac{P^{*}}{\mathrm{DNI}^{*}} \mathrm{DNI}\left(1-\delta\left(T_{c}-T_{c}^{*}\right)\right) \\
& \times\left(1-\varepsilon\left(\mathrm{AM}-\mathrm{AM}_{\mathrm{U}}\right)\right) \\
& \times\left(1-\varphi\left(\mathrm{AOD}_{550}-\mathrm{AOD}_{550, \mathrm{U}}\right)\right)
\end{aligned}
$$

where $\varphi$ is the aerosol optical depth coefficient of the maximum power of a HCPV module and $\mathrm{AOD}_{550, \mathrm{U}}$ is the umbral aerosol optical depth at $550 \mathrm{~nm}$. This equation quantifies the $\mathrm{AOD}$ at $550 \mathrm{~nm}$ since it is the most common observed value in different aerosol data bases.

Equations (1), (2), and (3) need cell temperature in order to estimate the maximum power of a HCPV module. This temperature is calculated from atmospheric parameters using the equation introduced by Almonacid et al. [34] as

$$
T_{\text {cell }}=T_{\text {air }}+a \mathrm{DNI}+b W_{s}
$$

where $T_{\text {air }}$ is the air temperature, $W_{s}$ is the wind speed, and $a$ and $b$ are coefficients specific to each HCPV module. This equation has been widely analysed and has showed a good performance in the estimation of cell temperature of a HCPV module [35].

\section{Experimental Campaign}

In order to check the quality of the model described in the last section, a HCPV module was under study at the Centre of Advanced Studies in Energy and Environment (CEAEMA) at the University of Jaen in Southern Spain (N $37^{\circ} 27^{\prime} 36^{\prime \prime}$, W $03^{\circ} 28^{\prime} 12^{\prime \prime}$ ) from July 2013 to June 2014. The HCPV module was mounted on a high accuracy twoaxis solar tracker located on the roof of the research centre (Figure 3(a)). Tables 1 and 2 show the main characteristics and maximum power at standard test conditions (STC) of the HCPV module. In order to measure the electrical
TABLE 1: Characteristics of the high concentrator photovoltaic module used in the study. Every cell is protected with a bypass diode.

\begin{tabular}{lc}
\hline Geometric concentration & 700 \\
Primary optics & SOG squared flat Fresnel lens \\
Secondary optics & Reflexive truncated pyramid \\
Optical efficiency & 0.80 \\
Type of solar cells & Lattice-matched GaInP/GaInAs/Ge \\
Solar cells area & $0.763 \mathrm{~cm}^{2}$ \\
Number of solar cells & 20 \\
Cooling & Passive \\
\hline
\end{tabular}

TABle 2: Maximum power of the high concentrator photovoltaic module considered at standard test conditions (STC).

\begin{tabular}{lccc}
\hline$P(\mathrm{~W})$ & $\mathrm{DNI}\left(\mathrm{W} / \mathrm{m}^{2}\right)$ & $T_{\text {cell }}\left({ }^{\circ} \mathrm{C}\right)$ & Spectrum \\
\hline 280 & 1000 & 25 & AM1.5d \\
\hline
\end{tabular}

parameters of the HCPV module a four-wire electronic load was used. Also, two four-wire PT100 were installed. One thermometer was placed close to the solar cell to measure its temperature (Figure 3(c)) and the other was placed on the back of the module to measure its heat-sink temperature. These thermometers were connected to a data logger to record both temperatures. It is important to note that the sensors were located in a receiver between the centre and the border of the module, so that the measured temperatures should be considered as the average temperature of a receiver due to the temperature distribution of a HCPV module [36]. This approach has been previously used and is considered as an adequate procedure for estimating the cell temperature of a HCPV module and for its electrical characterization [37, 38]. In addition, an atmospheric station (Figure 3(b)) recorded the main atmospheric parameters such as direct normal irradiance, air temperature, wind speed, or humidity. All the parameters were recorded daily every 5 minutes. Figure 3(d) shows the scheme of the experimental set-up. In addition, the daily average values of aerosol optical depth at $550 \mathrm{~nm}$ not provided by the atmospheric station were obtained from MODIS Daily Level-3 data source [39].

Figure 4 shows the distribution of the parameters needed to apply the models described in Section 2, obtained during the experiment. Based on these parameters and performing different regression analysis, the coefficients of the models for the module considered have been obtained, as shown in Table 3 .

\section{Analysis of Results}

In order to check the quality of the proposed model different analyses have been conducted. Figure 5 shows the linear regression analysis between actual and predicted data using (3) and (4) and the coefficients empirically obtained for the module considered; see Table 3. As can be seen, the model presents an almost perfect fit with a slope equal to 1 and determination coefficient $\left(R^{2}\right)$ of 0.99 . Also, different statistical parameters have been calculated: the root mean square error (RMSE), the mean absolute error (MAE), and the mean bias 


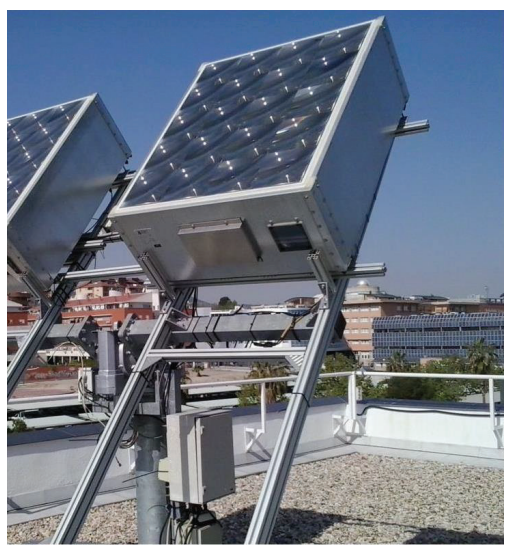

(a)

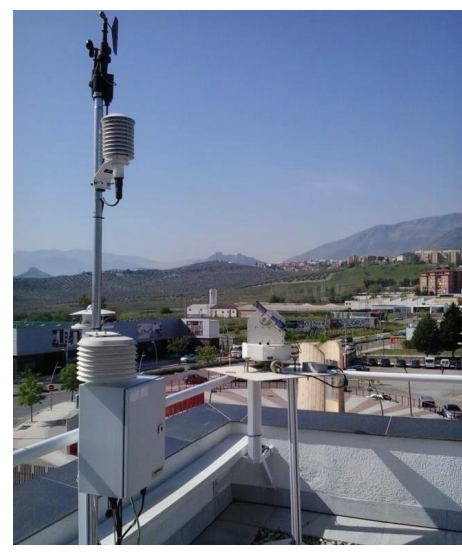

(b)

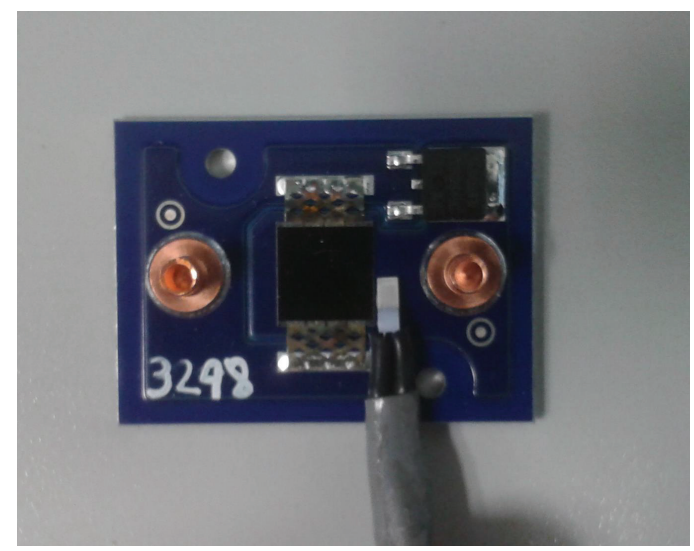

(c)

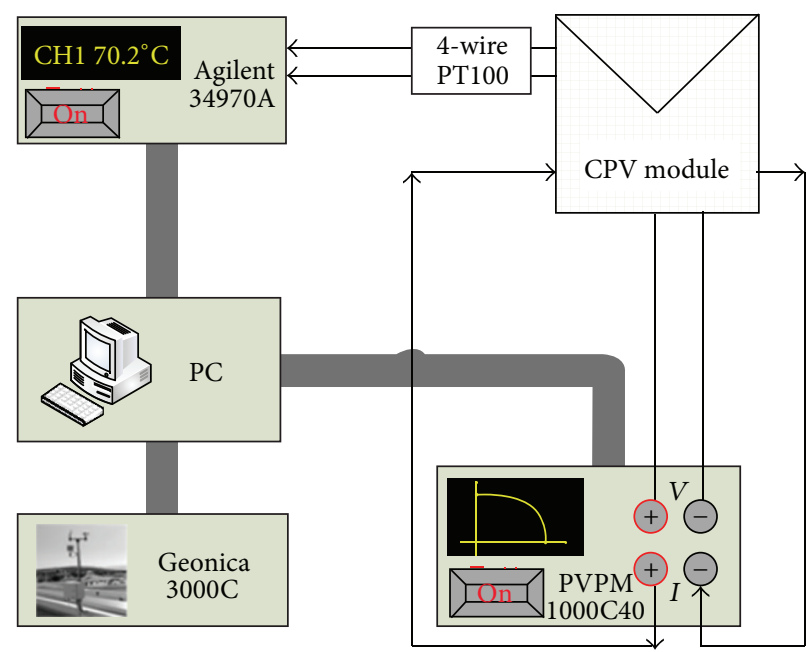

(d)

Figure 3: Experimental set-up used to carry out the study at the Centre of Advanced Studies in Energy and Environment of the University of Jaen.

TABLE 3: Values of the coefficients obtained from outdoor monitored data for estimating the maximum power of the HCPV module considered.

\begin{tabular}{lc}
\hline Coefficient & Value \\
\hline$a\left({ }^{\circ} \mathrm{C} / \mathrm{Wm}^{-2}\right)$ & 0.044 \\
$b\left({ }^{\circ} \mathrm{C} / \mathrm{ms}^{-1}\right)$ & -3.41 \\
$\delta\left(1 /{ }^{\circ} \mathrm{C}\right)$ & 0.0016 \\
$\varepsilon$ (dimensionless) & 0.041 \\
$\mathrm{AM}_{\mathrm{U}}$ (dimensionless) & 2.10 \\
$\varphi($ dimensionless $)$ & 0.32 \\
$\mathrm{AOD}_{550, \mathrm{U}}$ (dimensionless) & 0.25 \\
\hline
\end{tabular}

error $(\mathrm{MBE})$. The model shows a $\mathrm{RMSE}=2.67 \%$ and a MAE $=4.23 \mathrm{~W}$ which indicates the small variation of predicted data around measured data and taking into account that the HCPV module considered has a maximum power of $280 \mathrm{~W}$ at STC. The model shows $\mathrm{MBE}=0.19 \%$ which neither overestimates nor underestimates the maximum power.
As commented, the output of a HCPV module is mainly given by direct normal irradiance, cell temperature, and incident spectrum. In order to evaluate the behaviour of the model versus these parameters, Figure 6 shows the RMSE for different DNI, $T_{c}$, and SF levels. The spectral factor is obtained using the procedures previously described by different authors [40-44]. Figure 6(a) shows the RMSE versus DNI. As can be seen, the model shows a good performance for all DNI levels with a RMSE almost constant ranging from $1 \%$ to $2 \%$, although it trends to increase with DNI until a maximum value at around 3\%. Figure 6(b) shows the RMSE versus $T_{c}$. The model also shows a good performance for all $T_{c}$ values with a RMSE ranging from around $2.5 \%$ to $0.8 \%$. As can also be seen, the model yields better results for high $T_{c}$ values. Figure 6(c) shows the RMSE versus SF. As can be seen, the model yields good results at different spectra with a RMSE ranging from around $1 \%$ to $2.8 \%$. Also, it can be concluded that the model yields poorest results as the SF increases.

In addition to the analyses conducted, a comparison between the results obtained with the proposed model and the results obtained using models based on (1) and (2) has 


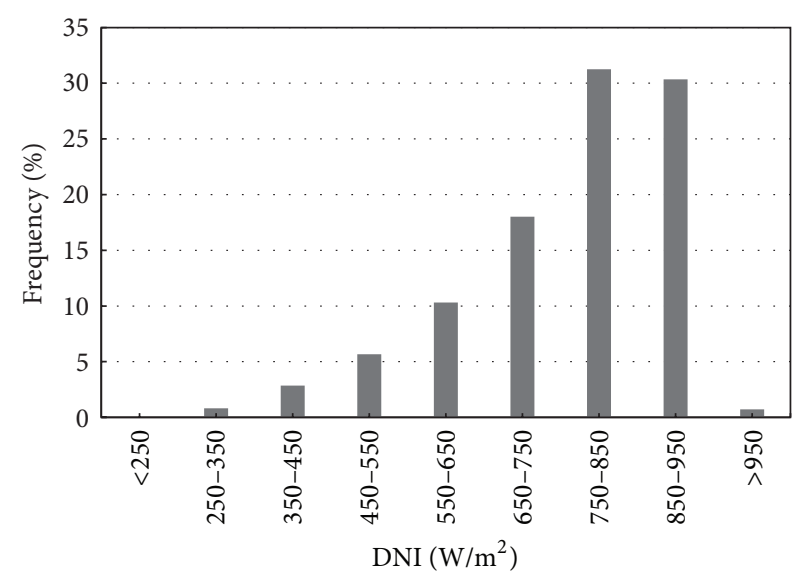

(a)

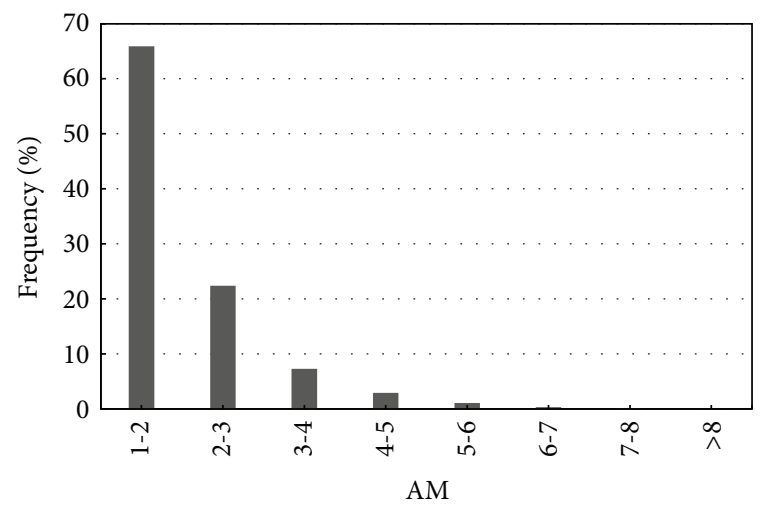

(c)

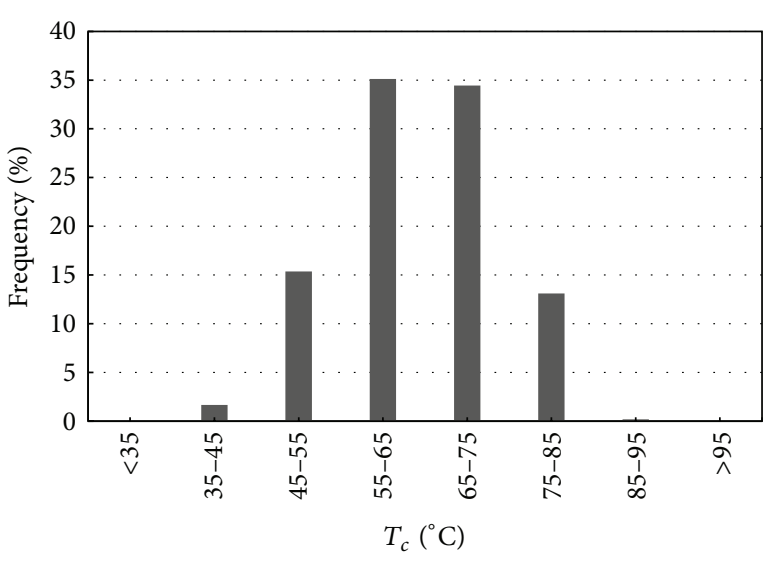

(b)

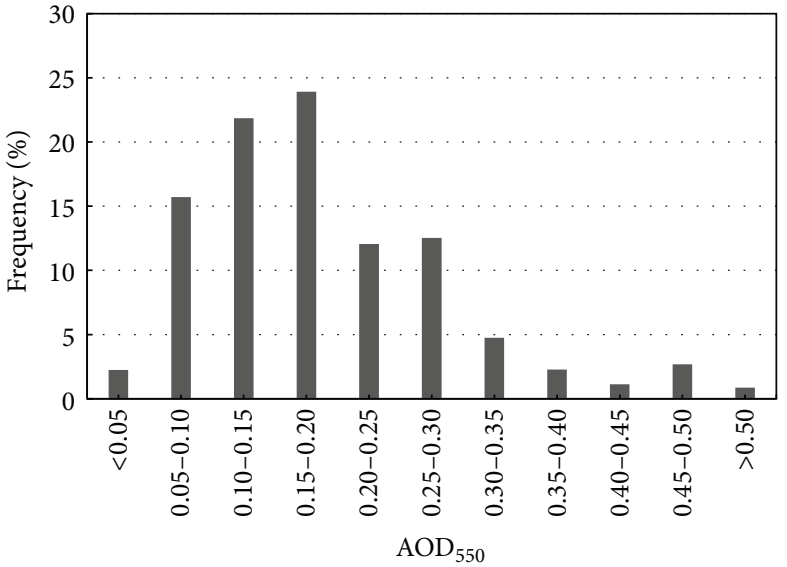

(d)

FiguRE 4: Frequency of the direct normal irradiance (a), the cell temperature (b), the air mass (c), and the aerosol optical depth at $550 \mathrm{~nm}$ (d) measured during the experimental campaign.

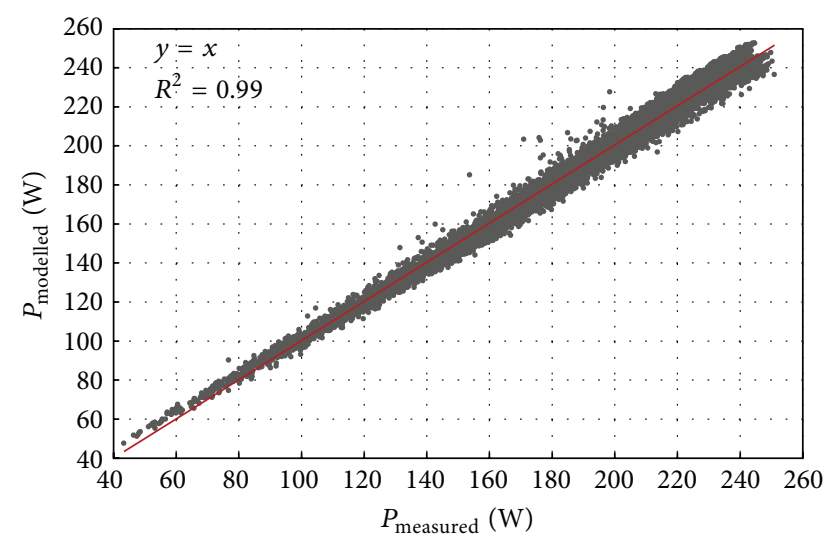

FIGURE 5: Linear regression analysis between measured and predicted data for the proposed model for the HCPV considered.

been carried out, as shown in Table 4. As can be seen, the proposed model significantly improves the results of the model based on (1). This can be explained since this model does not take into account any spectral correction. Regarding the comparison with the model based on (2), the proposed model also improves the results which demonstrates the better performance of the proposed model based on an additional spectral correction based on $\mathrm{AOD}_{550}$. It is important to note that Jaen is a nonindustrialized medium-size city with low-medium values of aerosol optical depth as shown in Figure 4(d). Because of this, although the proposed model has a better performance, the results obtained with the model based on (2) and on (3) are similar. However, the proposed model is expected to significantly improve the results of the model only based on AM correction at locations with high turbidity where the AOD plays an important role on the performance of HCPV modules [15].

\section{Conclusions}

In this paper a mathematical model for estimating the maximum power of a HCPV module has been introduced. Following the approach presented by Fernández et al. [14], the proposed model is based on atmospheric parameters and simple mathematical equations in order to facilitate its application. The model introduces a new spectral correction 


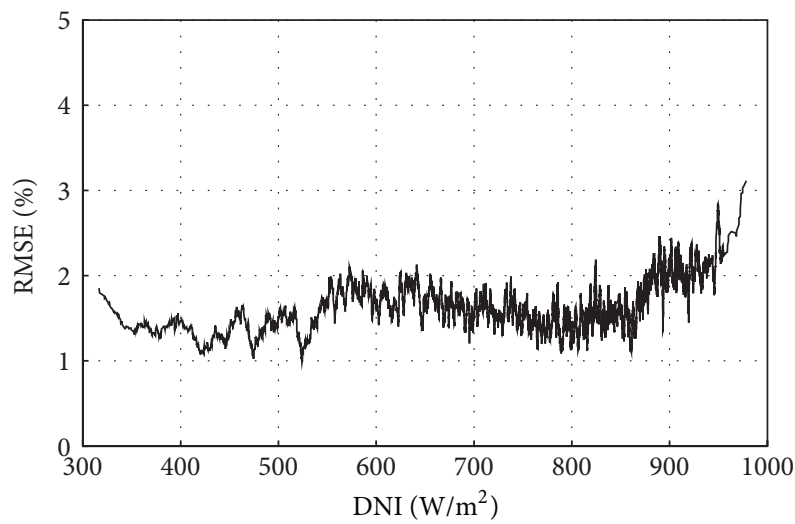

(a)

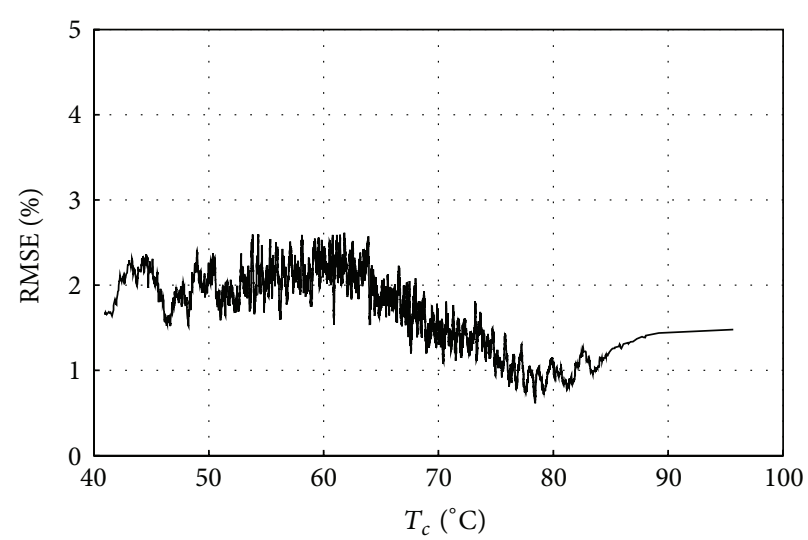

(b)

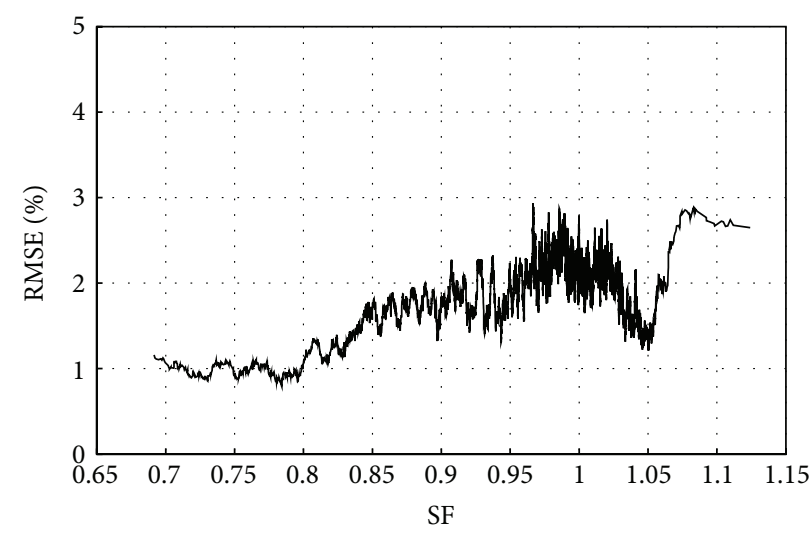

(c)

FIGURE 6: Root mean square error (RMSE) for different DNI, $T_{c}$, and SF levels for the proposed model for the HCPV considered.

TABLE 4: Root mean square error (RMSE), mean absolute error (MAE), mean bias error (MBE), and determination coefficient $\left(R^{2}\right)$ obtained for the three models described in Section 2.

\begin{tabular}{lcccc}
\hline Model & RMSE (\%) & MAE $(\mathrm{W})$ & MBE (\%) & $R^{2}$ \\
\hline DNI, $T_{\text {cell }}$ & 4.96 & 7.46 & 0.42 & 0.92 \\
DNI, $T_{\text {cell }}, \mathrm{AM}$ & 3.53 & 5.58 & -0.32 & 0.98 \\
DNI, $T_{\text {cell }}, \mathrm{AM}, \mathrm{AOD}$ & 2.67 & 4.23 & 0.19 & 0.99 \\
\hline
\end{tabular}

based on aerosol optical depth, so that is valid for sites with high turbidity. The analysis of the results shows that the model has a good performance in the prediction of the maximum power of a HCPV module with a RMSE $=2.67 \%$, a MAE of $4.23 \mathrm{~W}$, a MBE of around $0 \%$, and $R^{2}$ of 0.99 . Furthermore, the model improves the results obtained with the model previously introduced by the authors only based on an air mass correction. So the model can be considered as a new useful tool for the prediction of the electrical output of HCPV modules under diverse climate conditions.

\section{Conflict of Interests}

The authors declare that there is no conflict of interests regarding the publication of this paper.

\section{Acknowledgments}

Partial funding for this study was provided through EPSRC funded BioCPV (EP/J000345/1) project. Also, this work is part of the project "Desenvolvemento de novos conceptos baseados en tecnoloxía de concentración fotovoltaica para a produción de enerxía eléctrica adaptados a distintas zonas climáticas," through the program "Formación Posdoutoral do Plan Galego de Investigación, Innovación e Crecemento 2011-2015 (Plan I2C)" funded by the Xunta de Galicia and by the European Social Fund.

\section{References}

[1] A. Luque, G. Sala, and I. Luque-Heredia, "Photovoltaic concentration at the onset of its commercial deployment," Progress in Photovoltaics: Research and Applications, vol. 14, no. 5, pp. 413$428,2006$.

[2] M. Khamooshi, H. Salati, F. Egelioglu, A. Hooshyar Faghiri, J. Tarabishi, and S. Babadi, "A review of solar photovoltaic concentrators," International Journal of Photoenergy, vol. 2014, Article ID 958521, 17 pages, 2014.

[3] H. Cotal, C. Fetzer, J. Boisvert et al., "III-V multijunction solar cells for concentrating photovoltaics," Energy \& Environmental Science, vol. 2, no. 2, pp. 174-192, 2009. 
[4] G. Zubi, J. L. Bernal-Agustín, and G. V. Fracastoro, "High concentration photovoltaic systems applying III-V cells," Renewable and Sustainable Energy Reviews, vol. 13, no. 9, pp. 2645-2652, 2009.

[5] W. T. Xie, Y. J. Dai, R. Z. Wang, and K. Sumathy, "Concentrated solar energy applications using Fresnel lenses: a review," Renewable \& Sustainable Energy Reviews, vol. 15, no. 6, pp. 2588-2606, 2011.

[6] M. Victoria, C. Domínguez, I. Antón, and G. Sala, "Comparative analysis of different secondary optical elements for aspheric primary lenses," Optics Express, vol. 17, no. 9, pp. 6487-6492, 2009.

[7] H. Baig, K. C. Heasman, and T. K. Mallick, "Non-uniform illumination in concentrating solar cells," Renewable \& Sustainable Energy Reviews, vol. 16, no. 8, pp. 5890-5909, 2012.

[8] M. Yamaguchi, T. Takamoto, K. Araki, and N. Ekins-Daukes, "Multi-junction III-V solar cells: current status and future potential," Solar Energy, vol. 79, no. 1, pp. 78-85, 2005.

[9] P. Pérez-Higueras, E. Muñoz, G. Almonacid, and P. G. Vidal, "High concentrator PhotoVoltaics efficiencies: present status and forecast," Renewable \& Sustainable Energy Reviews, vol. 15, no. 4, pp. 1810-1815, 2011.

[10] F. Dimroth, M. Grave, P. Beutel et al., "Wafer bonded fourjunction GaInP/GaAs//GaInAsP/GaInAs concentrator solar cells with $44.7 \%$ efficiency," Progress in Photovoltaics: Research and Applications, vol. 22, no. 3, pp. 277-282, 2014.

[11] K. Ghosal, S. Burroughs, K. Heuser, D. Setz, and E. GarralagaRojas, "Performance results from micro-cell based high concentration photovoltaic research development and demonstration systems," Progress in Photovoltaics: Research and Applications, vol. 21, no. 6, pp. 1370-1376, 2013.

[12] K. Ghosal, D. Lilly, J. Gabriel et al., "Semprius field results and progress in system development," IEEE Journal of Photovoltaics, vol. 4, no. 2, pp. 703-708, 2014.

[13] Globaldata, "Concentrated Photovoltaics (CPV)—Global Market Size, Competitive Landscape and Key Country Analysis to 2020, UK," 2014.

[14] E. F. Fernández, F. Almonacid, P. Rodrigo, and P. PérezHigueras, "Model for the prediction of the maximum power of a high concentrator photovoltaic module," Solar Energy, vol. 97, pp. 12-18, 2013.

[15] E. F. Fernández, F. Almonacid, J. A. Ruiz-Arias, and A. SoriaMoya, "Analysis of the spectral variations on the performance of high concentrator photovoltaic modules operating under different real climate conditions," Solar Energy Materials \& Solar Cells, vol. 127, pp. 179-187, 2014.

[16] B. García-Domingo, J. Aguilera, J. de la Casa, and M. Fuentes, "Modelling the influence of atmospheric conditions on the outdoor real performance of a CPV (Concentrated Photovoltaic) module," Energy, vol. 70, pp. 239-250, 2014.

[17] N. L. A. Chan, T. B. Young, H. E. Brindley et al., "Validation of energy prediction method for a concentrator photovoltaic module in Toyohashi Japan," Progress in Photovoltaics: Research and Applications, vol. 21, no. 8, pp. 1598-1610, 2013.

[18] M. Steiner, G. Siefer, T. Hornung, G. Peharz, and A. W. Bett, "YieldOpt, a model to predict the power output and energy yield for concentrating photovoltaic modules," Progress in Photovoltaics: Research and Applications, 2014.

[19] P. Rodrigo, E. F. Fernández, F. Almonacid, and P. J. PérezHigueras, "Models for the electrical characterization of high concentration photovoltaic cells and modules: a review," Renewable and Sustainable Energy Reviews, vol. 26, pp. 752-760, 2013.
[20] N. L. A. Chan, H. E. Brindley, and N. J. Ekins-Daukes, "Impact of individual atmospheric parameters on CPV system power, energy yield and cost of energy," Progress in Photovoltaics: Research and Applications, vol. 22, no. 10, pp. 1080-1095, 2014.

[21] S. Kurtz, M. Muller, D. Jordan et al., "Key parameters in determining energy generated by CPV modules," Progress in Photovoltaics: Research and Applications, 2014.

[22] E. F. Fernández, P. Pérez-Higueras, A. J. Garcia Loureiro, and P. G. Vidal, "Outdoor evaluation of concentrator photovoltaic systems modules from different manufacturers: first results and steps," Progress in Photovoltaics: Research and Applications, vol. 21, no. 4, pp. 693-701, 2013.

[23] C. R. Osterwald, K. A. Emery, and M. Muller, "Photovoltaic module calibration value versus optical air mass: the air mass function," Progress in Photovoltaics: Research and Applications, vol. 22, no. 5, pp. 560-573, 2014.

[24] W. E. McMahon, K. E. Emery, D. J. Friedman et al., "Fill factor as a probe of current-matching for $\mathrm{GaInP}_{2} / \mathrm{GaAs}$ tandem cells in a concentrator system during outdoor operation," Progress in Photovoltaics: Research and Applications, vol. 16, no. 3, pp. 213224, 2008.

[25] M. Muller, B. Marion, S. Kurtz, and J. Rodriguez, "An investigation into spectral parameters as they impact CPV module performance," in Proceedings of the 6th International Conference on Concentrating Photovoltaic, vol. 1277, pp. 307-311, AIP, Freiburg, Germany, April 2010.

[26] C. R. Osterwald, "Translation of device performance measurements to reference conditions," Solar Cells, vol. 18, no. 3-4, pp. 269-279, 1986.

[27] D. L. Evans, "Simplified method for predicting photovoltaic array output," Solar Energy, vol. 27, no. 6, pp. 555-560, 1981.

[28] E. F. Fernández, F. Almonacid, N. Sarmah et al., "Performance analysis of the lineal model for estimating the maximum power of a HCPV module in different climate conditions," in Proceedings of the 10th International Conference on Concentrator Photovoltaic Systems (CPV '14), vol. 1616, pp. 187-190, Albuquerque, NM, USA, April 2014.

[29] G. Nofuentes, B. García-Domingo, J. V. Muñoz, and F. Chenlo, "Analysis of the dependence of the spectral factor of some PV technologies on the solar spectrum distribution," Applied Energy, vol. 113, pp. 302-309, 2014.

[30] M. Alonso-Abella, F. Chenlo, G. Nofuentes, and M. TorresRamírez, "Analysis of spectral effects on the energy yield of different PV (photovoltaic) technologies: the case of four specific sites," Energy, vol. 67, pp. 435-443, 2014.

[31] E. F. Fernández, G. Siefer, F. Almonacid, A. J. G. Loureiro, and P. Pérez-Higueras, "A two subcell equivalent solar cell model for III-V triple junction solar cells under spectrum and temperature variations," Solar Energy, vol. 92, pp. 221-229, 2013.

[32] C. Domínguez, I. Antón, and G. Sala, "Multijunction solar cell model for translating I-V characteristics as a function of irradiance, spectrum, and cell temperature," Progress in Photovoltaics: Research and Applications, vol. 18, no. 4, pp. 272284, 2010.

[33] G. Siefer and A. W. Bett, "Analysis of temperature coefficients for III-V multi-junction concentrator cells," Progress in Photovoltaics: Research and Applications, vol. 22, no. 5, pp. 515-524, 2014.

[34] F. Almonacid, P. J. Pérez-Higueras, E. F. Fernández, and P. Rodrigo, "Relation between the cell temperature of a HCPV module and atmospheric parameters," Solar Energy Materials \& Solar Cells, vol. 105, pp. 322-327, 2012. 
[35] E. F. Fernández, F. Almonacid, P. Rodrigo, and P. PérezHigueras, "Calculation of the cell temperature of a high concentrator photovoltaic (HCPV) module: a study and comparison of different methods," Solar Energy Materials \& Solar Cells, vol. 121, pp. 144-151, 2014.

[36] Y. Ota, H. Nagai, K. Araki, and K. Nishioka, "Temperature distribution in 820X CPV module during outdoor operation," AIP Conference Proceedings, vol. 1477, pp. 364-367, 2012.

[37] E. F. Fernández, P. Rodrigo, F. Almonacid, and P. PérezHigueras, "A method for estimating cell temperature at the maximum power point of a HCPV module under actual operating conditions," Solar Energy Materials and Solar Cells, vol. 124, pp. 159-165, 2014.

[38] E. Strobach, D. Faiman, S. Kabalo et al., "Modeling a gridconnected concentrator photovoltaic system," Progress in Photovoltaics: Research and Applications, 2014.

[39] “MODIS Daily Level-3 data," 2014, http://gdata1.sci.gsfc.nasa .gov/daac-bin/G3/gui.cgi?instance_id=MODIS_DAILY_L3.

[40] D. L. King, J. Kratochvil, W. E. Boyson, and W. I. Bower, "Field expererience with a new performance characterization procedure for photovoltaic arrays," in Proceedings of the 2nd World Conference and Exhibition on Photovoltaic Solar Energy Conversion, Vienna, Austria, July 1998.

[41] D. L. King, J. A. Kratochvil, and W. E. Boyson, "Measuring solar spectral and angle-of-incidence effects on photovoltaic modules and solar irradiance sensors," in Proceedings of the IEEE 26th Photovoltaic Specialists Conference, pp. 1113-1116, Anaheim, Calif, USA, October 1997.

[42] A. H. Fanney, B. P. Dougherty, and M. W. Davis, "Short-term characterization of building integrated photovoltaic panels," Journal of Solar Energy Engineering, vol. 125, no. 1, pp. 13-20, 2003.

[43] A. Fanney, M. Davis, B. Dougherty, D. King, W. Boyson, and J. Kratochvil, "Comparison of photovoltaic module performance measurements," in Proceedings of the International Solar Energy Conference, Orlando, Fla, USA, 2005.

[44] E. F. Fernández and F. Almonacid, "Spectrally corrected direct normal irradiance based on artificial neural networks for high concentrator photovoltaic applications," Energy, vol. 74, pp. 941949, 2014. 

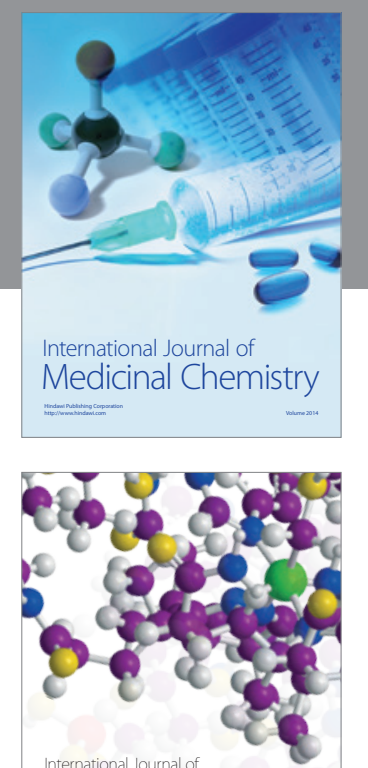

\section{Carbohydrate} Chemistry

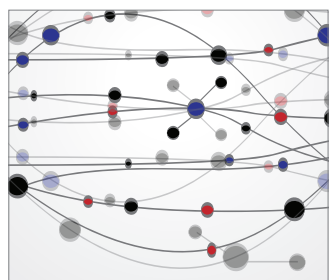

The Scientific World Journal
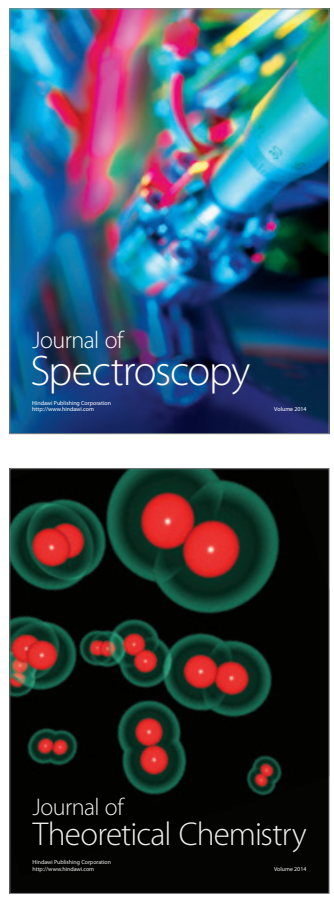
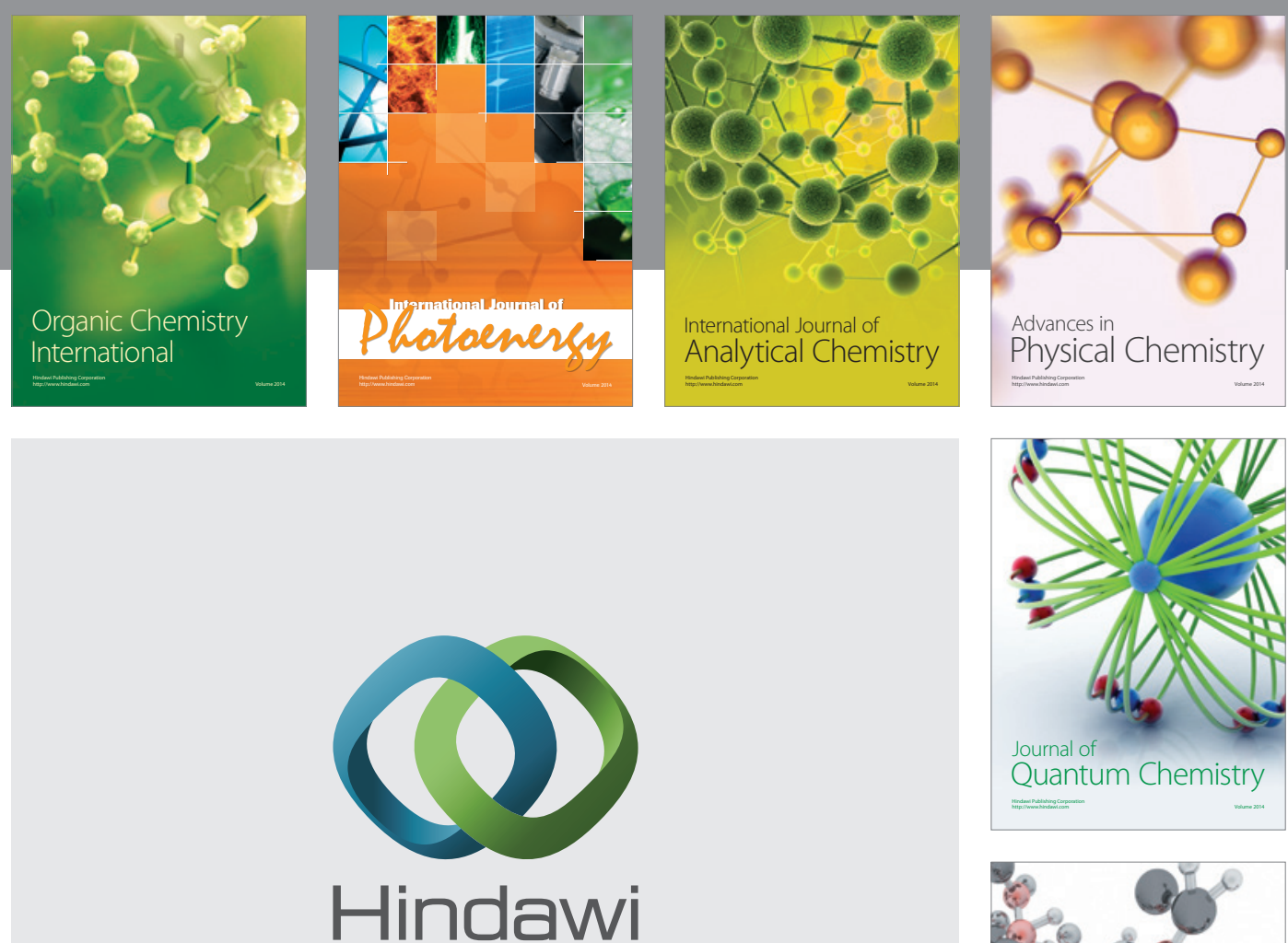

Submit your manuscripts at

http://www.hindawi.com

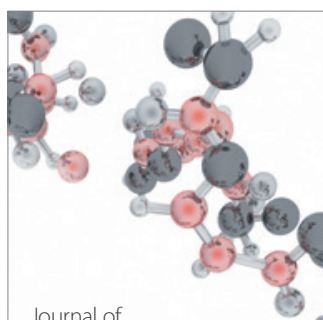

Analytical Methods

in Chemistry

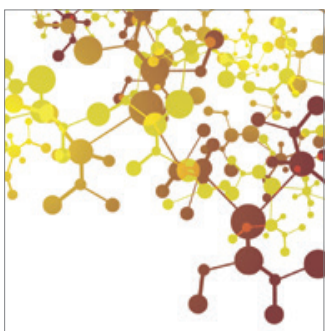

Journal of

Applied Chemistry

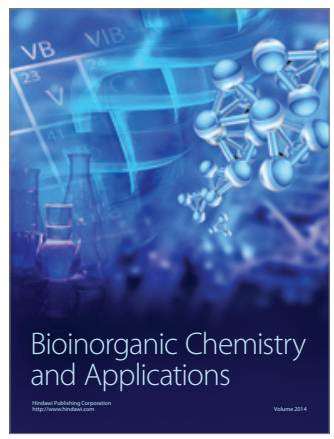

Inorganic Chemistry
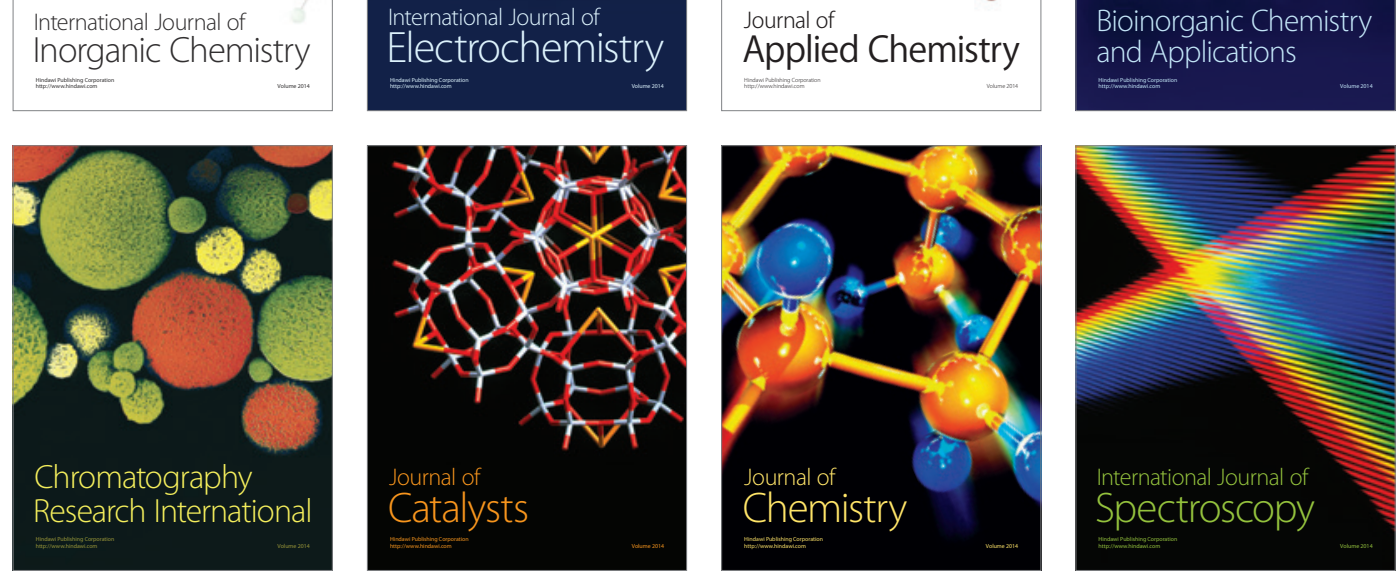